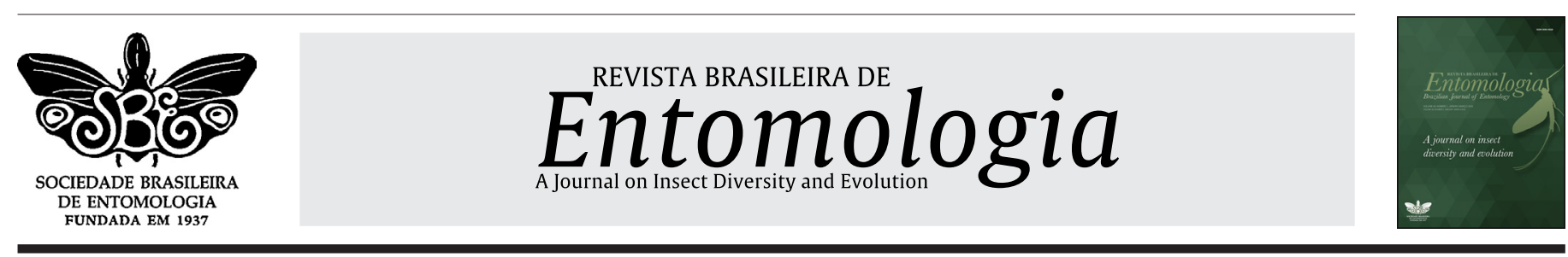

\title{
Flower perianth: first observations on a novel diet item for the ponerine ant Odontomachus chelifer (Latreille)
}

\author{
Ana Gabriela Delgado Bieber ${ }^{1,2, *}$ (D), Eduardo Roberto Pereira ${ }^{3}$, Claudia Bottcher ${ }^{1,2}$ (D) \\ ${ }^{1}$ Universidade Estadual de Campinas, Programa de Pós-Graduação em Ecologia, Campinas, SP, Brasil. \\ ${ }^{2}$ Universidade Estadual do Sudoeste da Bahia (UESB), Campus Itapetinga, Laboratório de Biossistemática Animal, Itapetinga, BA, Brasil. \\ ${ }^{3}$ Parque Estadual da Ilha do Cardoso, Cananéia, SP, Brasil.
}

\section{A R T I C L E I N F O}

Article history:

Received 3 March 2020

Accepted 3 August 2020

Available online 11 September 2020

Associate Editor: Ricardo Solar

\section{Keywords:}

Flower nectar

Iridaceae

Neomarica candida

Ponerinae, restinga forest

\begin{abstract}
A B S T R A C T
Ants are known to feed on a variety of plant resources. Nevertheless, there are very few reports in the literature on ants using flower parts. Here, we describe how two Odontomachus chelifer(Latreille) ants teared and removed a part of an inner tepal of a Neomarica candida (Hassl.) (Iridaceae) flower at the restinga sandy forest in the Cardoso Island State Park, Brazil. To determine which part of the perianth attracted these ants, we performed two independent two-choice field assays: tepals (inner and outer tepals) were cut in two parts (basal and apical), with contrasting colors, which were offered to ants leaving a colony. Our results show that ants significantly preferred to remove or lick the basal part of the inner tepal. Based on the knowledge of $N$. candida's floral anatomy, we hypothesize that ants were attracted by the nectar produced by trichomatic nectaries at the basal part of the inner tepals. These tepal parts containing nectar are likely to be used as an alternative food resource amid the scarcity of arthropods usually preyed or scavenged by $O$. chelifer, since the restinga forest is known as an arthropod-poor habitat.
\end{abstract}

Ants frequently gather their food directly or indirectly from plants (Davidson et al., 2003; Rico-Gray and Oliveira, 2007). Concerning flowers, ant visitation to floral nectaries is rather common (Haber et al., 1981; Rico-Gray and Oliveira, 2007). However, there are very few records of non-fungus-growing ants harvesting parts of flower perianth (sepals and petals, or tepals). For instance, Cerdá et al. $(1992,1996)$ described that entire petals, already fallen, of Halimium halimifolium (Cistaceae) are a major component of the diet of the formicine Cataglyphis floricola in the Iberian Peninsula, during summer. Similarly, a small set of studies collectively indicate that perianth is used by ants, but the evidence is scant (see Appendix 1 for a short review).

The trap-jaw ant genus Odontomachus (Formicidae: Ponerinae) includes primarily carnivorous ants, whose diet consists mainly of preyed and scavenged arthropods (Ehmer and Hölldobler, 1995; Raimundo et al., 2009). Nonetheless, feeding interactions of these ants with plant-derived resources are also known. Odontomachus were registered interacting with fleshy or arilate fruits (e.g., Pizo et al., 2005; Bottcher et al., 2016), as well as feeding on extrafloral nectaries (EFNs) (e.g., Schemske, 1982). There are also reports of Odontomachus using honeydew produced by phloem-feeding hemipterans (e.g., Evans and Leston, 1971; Souza and Francini, 2010). Here, we report on a new interaction of Odontomachus chelifer(Latreille) with plants: the active removal of flower perianth parts. We first document the behavior of workers tearing up a tepal from the flower of Neomarica candida(Hassl.) Sprague (tribe Trimezieae; Iridaceae) at the restinga, a sandy coastal plain forest, of the Cardoso Island $\left(25^{\circ} 18^{\prime} \mathrm{S}, 47^{\circ} 53^{\prime} \mathrm{W}\right)$, São Paulo State, Brazil. Secondly, we describe two-choice field assays for exploring which part of the floral perianth in fact attracted $O$. chelifer workers. Finally, we discuss the significance/novelty of our findings.

\section{Field observations}

On a February 2008 day, close to midday, two O. cheliferants were incidentally observed while they teared up and removed a part of one inner tepal of a $N$. candida flower (Fig. 1; and video, Supplementary Material). The flower observed was previously intact and situated $c a .10 \mathrm{~cm}$ above the ground. Flower stem was touching the ground making it easy for a non-flying insect to reach the flower. During our observations, the two ants worked together (Fig. 1A). Eventually, one ant left the target tepal and inspected the other tepals of the same flower, the nearest leaf or even the ground, returning to tear the tepal apart. Because the mandibles of $O$. chelifer are not specialized for cutting, such as those of leaf-cutter ants (Atta and Acromyrmex genera), the ants tried to grasp the tepal with their forceps-like mandible and then pulled it (Fig. 1B).

\footnotetext{
* Corresponding author:

E-mail: gabieber@gmail.com (A. G. D. Bieber)
} 
After tearing the target tepal, the ants carried, sometimes one of them, sometimes both, the tepal piece to their nest, situated on the ground, ca. $2 \mathrm{~m}$ away from flower location (Fig. 1C). We were not able to record the final use of the tepal, because the laden ants entered the nest. This initial observation lasted for around five minutes, but we cannot state the exact duration of the whole action since we did not observe the initial discovery of this flower by the ants.

\section{Plant description}

The Neotropical genus Neomarica (Sprague, 1928) is composed of about 24 species of evergreen herbs, distributed mainly in the Atlantic Forest (Oliveira et al., 2016). It belongs to Iridaceae, a cosmopolitan family whose Neotropical representatives (Tribes Sisyrinchieae, Trimezieae, and Tigridieae) may present flowers that produce lipids (floral oils) in specialized glands (elaiophores) as a reward to their bee pollinators (Vogel, 1974; Cocucci and Vogel, 2001; Rudall et al., 2003). However, the genus Neomarica does not bear elaiophores and, instead, secrets floral nectar on unicellular, elongated or balloon-like, trichomes, situated at the basal portion of its three inner tepals (Vogel, 1974).

Neomarica candida flowers during spring and summer, from August to April (Gil, 2012). Its flowers are very conspicuous, presenting white outer tepals and violet inner tepals, both with a yellow and brown variegated part at their base (Fig. 1A, B). As described by Vogel (1974), nectar-secreting trichomes are situated at the basal variegated part of its inner tepals (indicated in Fig. 1B). Flowers are ephemeral, lasting for just one day (A.G.D. Bieber, personal observation). Anthesis occurred before our arrival at the field (i.e., before 08:00 h), and dehiscence usually began at around 15:00 h, when perianth collapses and rapidly shrivels to a partially liquefied rounded mass, as described by Cocucci and Vogel (2001) for Sisyrinchium spp. (Tribe Sysirinchieae: Iridaceae).

\section{Two-choice bioassays}

From April 11 to 13, 2008, we conducted two distinct two-choice field assays to determine which perianth part was attractive to the ants. Three distinct $O$. chelifer colonies were used. With a scissor, we cut an inner tepal of $N$. candida in two parts: a basal part, yellow/brown colored, and an apical part, violet. The criterion used to determine this division was visual, but the colors also indicate different functions and/or chemical composition (see Vogel, 1974 and Rudall et al., 2003, for floral description; and Fig. 1B). The two parts were offered at the same time (directly on the ground, ca. $2 \mathrm{~cm}$ apart from each other) to individual ants leaving the colony to forage. We waited until the ant perceived (i.e., antennated) both parts and, thereafter, started to record its behavior (ignoring, mandibulating, licking, or carrying any tepal part to the nest). After an observation period of five minutes, we scored the interaction either as " 0,0 ", if no clear interest was perceived to both tepal parts (i.e., both were ignored), or " 1,0 "|“ 0,1 ”, if one part was preferred by the ant. Afterward, all observed ants were removed to a box and just released back to their respective nest at the end of the day, avoiding pseudo-replication. We only carried out twenty tests with the three $O$. chelifer colonies, due to the small number of flowers available at that period of the year. In twelve of them, the ants preferred the yellow/brown basal part, and in the other eight tests, the ants ignored both parts. Usually, the ants licked, antennated, cleaned their antennas with their mouthparts, tried to grasp, and even removed the yellow/brown part. The preference for the yellow/brown basal inner tepal part was statistically significant (Sign test; $Z=3.17 ; N=20 ; p<0.01$ ). Interestingly, the preferred basal part is where the nectar-secreting trichomes are located (Vogel, 1974).
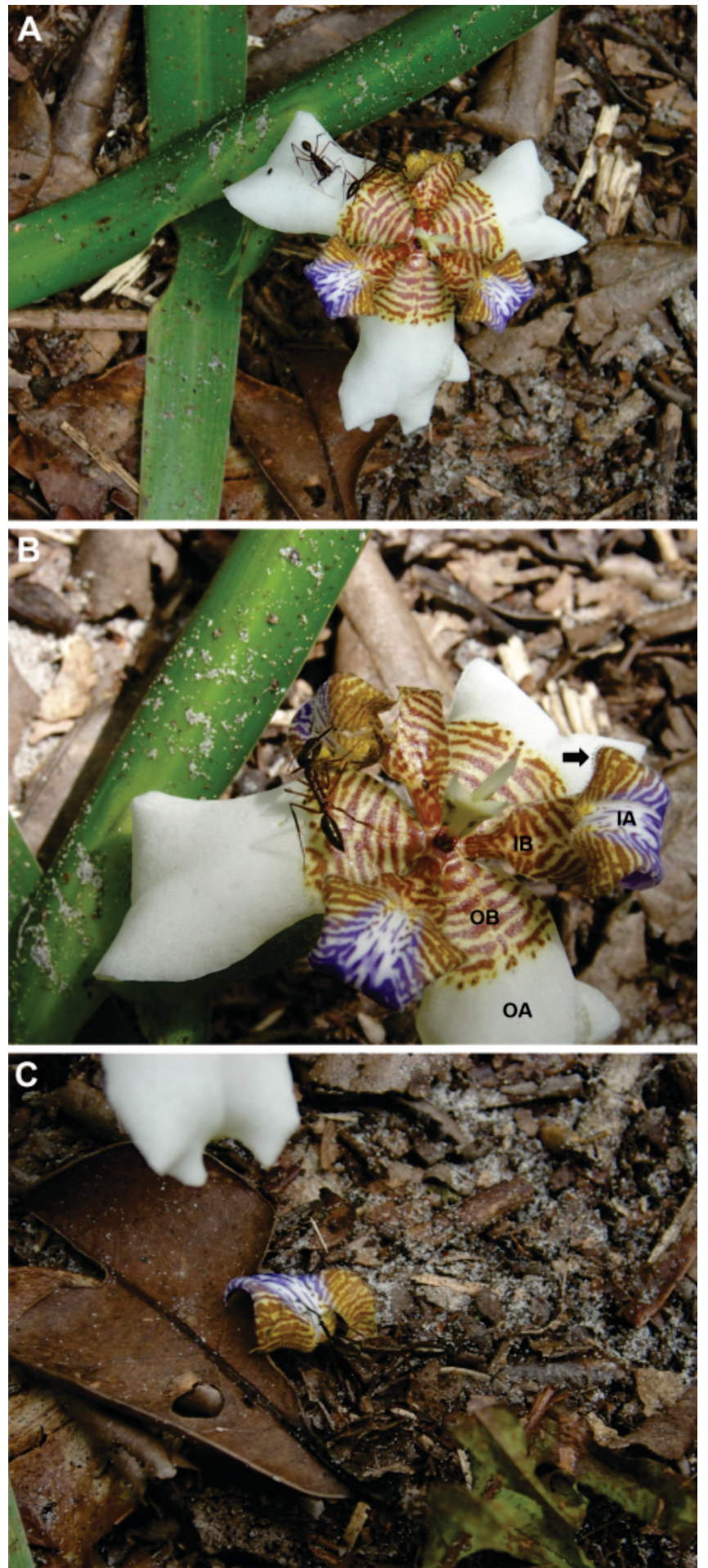

Figure 1 Three distinct moments of the interaction between Odontomachus cheliferant and the nectar-producing flower of Neomarica candida (Iridaceae) in the sandy coastal plain forest (restinga) of the Cardoso Island State Park, São Paulo State, Brazil: (A) Two ants attempting to tear up one of the inner tepals; (B) One ant pulling a partially teared tepal; and (C) one ant carrying the teared $N$. candida tepal piece to the nest. At (B), we indicate how tepals (inner/outer) were divided based on their different colors in two parts (basal/apical) for performing the two-choice tests: IB (inner tepal, basal part), IA (inner tepal, apical part), OB (outer tepal, basal part), and OA (outer tepal, apical part). The arrow indicates the location of some nectar-secreting trichomes.

We also conducted the same test described above using outer tepal parts (a basal yellow/brown part, and an apical white part). The same colonies were used and a total of 17 tests were conducted. In five of them, the ants dedicated longer periods for licking the yellow/brown 
part, but never carried it away. Once, an ant preferred the white tepal part, but also there was no removal. Regarding ant preferences, no significant difference between these two outer tepal parts was observed (Sign test; $\mathrm{Z}=1.22 ; \mathrm{N}=17 ; \mathrm{p}=0.22$ ).

\section{Discussion}

In this study, we have reported the incidental observation of two $O$. chelifer workers tearing up an $N$. candida flower and carrying one of its inner tepals to their nest. Based on the two-choice bioassays performed, we conclude that $O$. chelifer ants were interested in the nectar-producing structures (i.e., the basal parts of the inner tepals). Our observations allowed us to discard pollen as the resource sought, as it was never present on the tepal parts licked/taken by $O$. chelifer workers. Moreover, contrary to the already mentioned interaction of Cataglyphis with Halimium (Cerdá et al., 1996), tepal tissue itself does not seem to be attractive to these ants since during experimental assays ants ignored tepal parts without trichomatic nectaries. To our best knowledge, this is the first observation of any Odontomachus species tearing up perianth parts, as well as foraging for floral nectar, despite their already known use of homopteran honeydew and EFNs (e.g., Evans and Leston, 1971; Schemske, 1982; Souza and Francini, 2010).

In fact, the behavior detailed here is unusual either for carnivore or omnivore ants, especially ponerines, which is reinforced by the small number of published works recorded here ( $\mathrm{N}=11$, see Appendix 1). Nonetheless, spatio-temporal variability of arthropod prey supply might lead to a diversification in food items collected by these ants (Pizo et al., 2005; Bottcher et al., 2016). Specifically, the restinga of Cardoso Island is considered an arthropod-poor habitat (Pizo et al., 2005; Bottcher et al., 2016). For instance, the relative frequency of $O$. chelifer interaction with fleshy plant diaspores (also a protein-poor food source) is greater at this sandy forest in comparison to other Atlantic forest sites, whose values of overall productivity (litter thickness, humus layer, soil arthropod biomass) are higher (Pizo et al., 2005; Bottcher et al., 2016). Moreover, a study focusing on $O$. chelifer's foraging ecology, performed in a semideciduous Atlantic forest remnant, found that its mainly carnivorous diet remained quite constant between the two investigated seasons (wet/warm vs. dry/cold), without any record of plant-derived food (exudates or fruits) consumption (Raimundo et al., 2009).

Based on the above mentioned studies (Pizo et al., 2005; Bottcher et al., 2016), we hypothesize that $O$. chelifer uses the nectar-producing tepals of $N$. candida also due to the lower availability of arthropod prey at the restinga of Cardoso Island. Interestingly, most studies accounting for the foraging of petals by non-leaf-cutter ants (listed in Appendix 1) were also carried out in arid/semi-arid areas and/or vegetation types growing on poor soils. This fact reinforces the idea that, under scenarios of arthropod prey scarcity, predominantly carnivorous ants are more prone to include protein-poor food items on their diet. One of these items is flower parts, either harvested on the ground (Kugler and Hincapie, 1983; Cerdá et al., 1992, 1996; Belchior et al., 2012) or directly cut from plants (Halverson et al., 1976; this study). By doing this, ants would acquire mainly carbohydrates (energy), used for fueling their foraging activity in search of arthropod prey (mostly composed by proteins and lipids), essential for colony growth and reproduction (Davidson et al., 2003).

The removal of tepals by $O$. chelifer could potentially present detrimental consequences to the reproductive success of $N$. candida, and therefore we briefly discuss here some points. In some cases, ant visitation to flowers may hinder the visitation of other floral visitors, including effective pollinators (see Rico-Gray and Oliveira, 2007, for a review), but this does not seem to be true here. While ants were tearing up the tepal, we also observed two visits by workers of stingless bees
(Meliponini: Apidae) (video, Supplementary Material), which were ignored by the ants. Although the role of these bees as pollinators was not assessed by us, the absence of an aggressive behavior by the ants suggests that they do not exert a negative effect on pollination (e.g., Ness, 2006). Yet, from the perspective of possible flower visitors, damaged flowers may no longer be as attractive as undamaged flowers, as reported for Rhododendron macrophyllum (Weiser, 2002). The ephemeral nature of Neomarica flower (see 'Plant description') however, makes this very unlikely. Lastly, although worth of description, the new interaction described here is not frequent. In fact, Neomarica perianth does not seem to be the preferred choice of this ant species, contrary to what was observed by Cerdá et al. (1996) about C. floricola attraction to $H$. halimifolium. One of us studied $O$. chelifer's foraging, in this same locality and season (from October/2007 to March/2008), and recorded that more than $90 \%$ of the collected items were arthropods (similar figures were recorded by Raimundo et al., 2009), whereas less than $4.5 \%$ were plant materials (seeds, fruits, and leaf parts; Bottcher, 2010).

Finally, we hypothesize that damage to flower perianth by non-leaf-cutter ants should be more common, as well as ecologically relevant, under the following two conditions. First, we expect that, in arthropod-poor ecosystems/seasons, predominantly carnivorous ants may incorporate flower parts (or floral nectar) as alternative food resources (as some studies in Appendix 1), using the acquired energy for fueling their hunting/scavenging activity. Second, if nectar production occurs on the surface of soft petals/sepals, such as for the species $N$. candida, ants may damage the flowers for nectar harvesting. This may be especially true if the nectar is meant to feed other colony members, and the species does not present an expansible crop for temporary liquid storage (such as some Formicinae/Dolichoderinae), thus making necessary the removal of nectar-containing parts. In spite of this, some poneromorph ants, including the congeneric Odontomachus troglodytes, may be able to transport fluids as droplets within their mandibles (Evans and Leston, 1971; Paul and Roces, 2003).

\section{Acknowledgements}

We are grateful to ASB Gil for Neomarica candida identification, and to CEP Silva for bees identification. We also thank PS Oliveira for initial support on the study of this new observation and the Instituto Florestal do Estado de São Paulo for logistical support. The final version of this manuscript benefitted from suggestions made by three anonymous reviewers, as well as by PR Guimarães Jr., JM Nascimento and P Milet-Pinheiro. During fieldwork, AGDB and CB were granted doctoral fellowships from Fundação de Amparo à Pesquisa do Estado de São Paulo (FAPESP, grants \#07/54739-6 and \#05/59280-6, respectively). Posteriorly, CB benefited from a postdoctoral fellowship from Coordenação de Aperfeiçoamento de Pessoal de Nível Superior (PNPD-CAPES, grant linked to the Programa de Pós-Graduação em Ciências Ambientais; Universidade Estadual do Sudoeste da Bahia).

\section{Conflicts of interest}

The authors declare no conflicts of interest.

\section{Author contribution statement}

AGDB made the first observations on the interaction. All three authors designed and performed the experiments. AGDB and CB performed the literature review and wrote the first version of the manuscript. ERP prepared the supporting material (figures and video). All authors contributed to and approved the final version of this paper. 


\section{References}

Belchior, C., Del-Claro, K., Oliveira, P. S., 2012. Seasonal patterns in the foraging ecology of the harvester ant Pogonomyrmex naegelii (Formicidae, Myrmicinae) in a Neotropical savanna: daily rhythms, shifts in granivory and carnivory, and home range. Arthropod-Plant Interact. 6(4), 571-582. http://dx.doi.org/10.1007/s11829-012-9208-1.

Bottcher, C. 2010. O consumo de sementes e frutos carnosos por formigas em Mata Atlântica: História natural, ecologia e variação espacial de uma interação proeminente. PhD Thesis, Departamento de Zoologia, Universidade Estadual de Campinas.

Bottcher, C., Peixoto, P. E. C., Silva, W. R., Pizo, M. A., 2016. Drivers of spatial variation in the role of ants as secondary seed dispersers. Environ. Entomol. 45 (4), 930-937. http://dx.doi.org/10.1093/ee/nvw058.

Cerdá, X., Retana, J., Carpintero, S., Cros, S., 1992. Petals as the main resource collected by the ant Cataglyphis floricola(Hymenoptera: Formicidae). Sociobiology 20, 315-320.

Cerdá, X., Retana, J., Carpintero, S., Cros, S., 1996. An unusual ant diet: Cataglyphis floricola feeding on petals. Insectes Soc. 43, 101-104. http://dx.doi.org/10.1007/BF01253960.

Cocucci, A. A., Vogel, S., 2001. Oil-producing flowers of Sisyrinchium species (Iridaceae) and their pollinators in southern South America. Flora 196 (1), 26-46. http://dx.doi.org/10.1016/S0367-2530(17)30010-5.

Davidson, D. W., Cook, S. C., Snelling, R. R., Chua, T. H., 2003. Explaining the abundance of ants in lowland tropical rainforest canopies. Science 300 (5621), 969-972. http://dx.doi.org/10.1126/science.1082074.

Ehmer, B., Hölldobler, B., 1995. Foraging behavior of Odontomachus bauri on Barro Colorado Island, Panama. Psyche 102 (3-4), 215-224. http:// dx.doi.org/10.1155/1995/27197.

Evans, H. C., Leston, D., 1971. A ponerine ant (Hym., Formicidae) associated with Homoptera on cocoa in Ghana. Bull. Entomol. Res. 61 (2), 357362. http://dx.doi.org/10.1017/S0007485300057898.

Gil, A. S. B., 2012. Revisão taxonômica e estudos filogenéticos do gênero Neomarica s.l. (Iridaceae). PhD Thesis, Departamento de Botânica, Universidade Estadual de Campinas.

Haber, W. A., Frankie, G. W., Baker, H. G., Baker, I., Koptur, S., 1981. Ants like flower nectar. Biotropica 13(3), 211-214. http://dx.doi.org/10.2307/2388126.

Halverson, D. D., Wheeler, J., Wheeler, G. C., 1976. Natural History of the Sandhill Ant, Formica bradleyi (Hymenoptera: formicidae). J. Kans. Entomol. Soc. 49, 280-303.
Kugler, C., Hincapie, M. C., 1983. Ecology of the ant Pogonomyrmex mayri: distribution, abundance, nest structure, and diet. Biotropica 15 (3), 190-198. http://dx.doi.org/10.2307/2387828.

Ness, J. H., 2006. A mutualism's indirect costs: the most aggressive plant bodyguards also deter pollinators. Oikos 113 (3), 506-514. http://dx.doi. org/10.1111/j.2006.0030-1299.14143.x.

Oliveira, P. N., Gil, A. S., Giulietti, A. M., Oliveira, R. P., Amaral, M. C., 2016. Neomarica castaneomaculata and $N$. involuta(Iridaceae): two new endemic species from the Atlantic Forest, Brazil. Phytotaxa 286 (2), 89-98. http://dx.doi.org/10.11646/phytotaxa.286.2.3.

Paul, J., Roces, F., 2003. Fluid intake rates in ants correlate with their feeding habits. J. Insect Physiol. 49 (4), 347-357. http://dx.doi. org/10.1016/S0022-1910(03)00019-2.

Pizo, M. A., Passos, L., Oliveira, P. S., 2005. Ants as seeds dispersers of fleshy diaspores in Brazilian Atlantic forests. In: Forget, P.-M., Lambert, J.E., Hulme, P.E., Vander Wall, S.B., (Eds.), Seed fate: Predation and Secondary Dispersal. CABI Publishing, Wallingford, pp. 315-329. http://dx.doi.org/10.1079/9780851998060.0315.

Raimundo, R. L. G., Freitas, A. V. L., Oliveira, P. S., 2009. Seasonal patterns in activity rhythm and foraging ecology in the neotropical forest-dwelling ant, Odontomachus chelifer (Formicidae: Ponerinae). Ann. Entomol. Soc. Am. 102 (6), 1151-1157. http://dx.doi.org/10.1603/008.102.0625.

Rico-Gray, V., Oliveira, P. S., 2007. The Ecology and Evolution of Ant-Plant Interactions. 1st ed. The University of Chicago Press, Chicago. http:// dx.doi.org/10.7208/chicago/9780226713540.001.0001.

Rudall, P. J., Manning, J. C., Goldblatt, P., 2003. Evolution of floral nectaries in Iridaceae. Ann. Mo. Bot. Gard. 90 (4), 613-631. http:// dx.doi.org/10.2307/3298546.

Schemske, D. W., 1982. Ecological correlates of a neotropical mutualism: ant assemblages at Costus extrafloral nectaries. Ecology 63 (4), 932-941. http://dx.doi.org/10.2307/1937233.

Souza, T. S., Francini, R. B., 2010. First record of trophobiotic interaction between a ponerine ant and a cicadelid bug. Psyche: J. Entomol. 2020, 372385. https://doi.org/10.1155/2010/372385.

Vogel, S., 1974. Ölblumen und ölsammelnde Bienen. Trop. Subtrop. Pflanzenwelt 7, 285-547.

Weiser, W. D., 2002. Removal of Rhododendron macrophyllum petals by Camponotus modoc. West. N. Am. Nat. 62, 498-499.

\section{Supplementary material}

The following online material is available for this article:

Video (Supplementary material) - Field recording of two Odontomachus chelifer ants attempting to remove a part of an Neomarica candida inner tepal.

Appendix 1: List of previous studies presenting relevant information on ant species foraging for or carrying flower perianth parts (petals, sepals, or tepals) to their nests. References on the use of flowers by fungus-growing ants (subtribe Attina) were not included, since plant parts (including flowers) are commonly used for fungus-growing. 